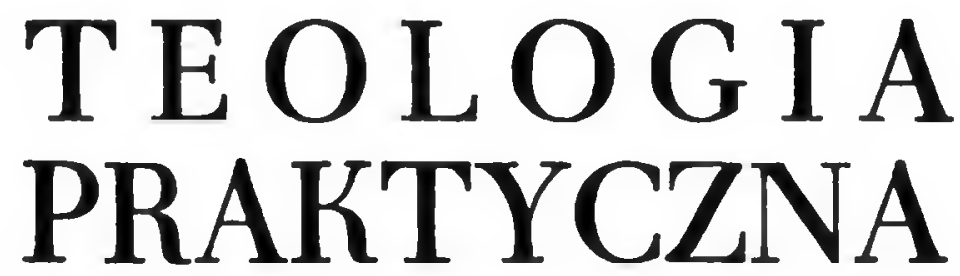

KWARTALNIK DLA DUSZPASTERZY

\title{
s. $\mathbf{F}_{\mathrm{p}}$
}

\section{KS. BISKUP ANTONI LAUBITZ.}

"Wielu chwalic bedzle madrost jego,

i at na wieki nle będzie wymazana,

i nie ustanie pamifc o nim.

to imie jego pytac sif będa ad narodu do narodu.

Medrost jego narody wyslawiac bedq.

- Koscidl chwale jego opowiadac bedzic."

Ks. Madr. Syr. 39, 12-14.

Pragnąc szkicować obraz sp. ks. bp. Laubitza trzeba by wlasciwie odstawic atrament, odlożyc papier i pioro, a wziąc na warsztat śpiż i marmur oraz Marcina Rożka twórcze dluto.

Gdy papież mianowal go w lisfopadzie 1924 r. biskupem tyfularnym jasseriskim mial pelnych lat szesćdziesiąt i trzy. Byl wiẹc wedlug pojecc potnocnych starcem nie do pastoralu, ale do laski sedziwości gotowym. Mądrośc Rzymu jak zawsze tak $i$ w tej nominacji okazala się w calej pelni. Przez lat piętnascie slużyl od switu do nocy Ko- 
sciolowi i Narodowi. $Z$ pelnym snopem czynow i zaslug stanąl przed Bogiem, aby zdać sprawe 2 wlodarstwa swego. Sp. biskup mial w sobie pewna twardosc, mozna by mówic o kujawskim uporze, może nawet nie bez slusznosci szeptalo się w dobrym znaczeniu o bezwzglęności "wladyki". Hisforyk z lat pózniejszych policzy jego wiekopomne dziela, zważy intencje - o ile to moźliwe - ustali sukcesy i stwierdzi sprawiedliwie, że takim musial byc, jakim byl, inaczej puste zostalyby po nim brogi.

Są ludzie, którzy rodzą się do wladzy l czynu.

Nawet bez zlocistej mitry i korony hrabstwa rzymskiego bylby sp. Zmarly zostawil wielkie nazwisko. Szedl bowiem od roboty do roboty, a zawsze w wielkim stylu.

Pan Bóg rzet́bil go też twardym dlutem krzyża. Pobudowal wspanialą, potężnę świątynię, chlubę Inowroclawia i Kujaw. W sam Wielki Piątek pochlonęla ziemia wielką jej częśc. Nie zolamal się robotnik boży. Na progu biskupstwa nowy krzyż niechybnie jeszcze boleśniejszy wlożyl mu Pan na barki. Przygarbil się na chwile, oczy zaszly mu mila. Potem stanal do pracy od porannej do wieczornej zorzy. Mial w duszy cos ze sredniowiecza, co to zostawilo strzeliste, niespozyte katedry, a slodka pobożnośc wdzięcznych kantylen miękkim czasom potomnych.

Pochlaniala go chwala boża. Dbal o niq̨ cala dusza, rozumem, wola nieugiętą, a takíe sercem, na oko ukrytym niby w stalowym schronie.

Gdyby niewdziecznosć ludzka chciala wymazac jego pamięc, podniosiby sprzeciw Wojciechdzwon, przez niego osadzony na podniebnym tronie wieży bazyliki. 
Sama macierz polskich kosciolów stanęlaby w monarszej krasie, glosząc czyny jego wśród wtoru miasta stolecznego prymasow, które w nowe przyodzial blaski.

Mądry byl, odważny w sprawach Kosciola $i$ narodu, dla biednych hojny, gospodarny $i$ goscinny wzorem Piasta.

Zaloba o niego podszyta jest cichą duma, że męża-kaplana takiej miary wydala Polska. Z jego trumną nie harmonizuja jakos lzy $i$ szlochy, raczej wydaje się na miejscu potrzaskiwanie tarczami, zbroi chrzęst i mieczów pobrzęk, niby na pochowie zolnierza wielkiej szarży $i$ slawy na miare Chrobrego, w którego pomniku najlepiej ksigdz biskup Laubitz wypowiedzial swoje aspiracje.

Byla mowa o krzyżach, nie wolno wiẹc przemilczec powodzenia i uznania, kfore mu towarzyszylo wiernie. Miad także, co się w swiecie nazywa szczęśiem.

Opatrznosc oddala go w rece Zwierzchnika, kfóry nie krępowal rozmachu, pochwala zachęcal, medal wybil na czesc jego, rozszerzal hojnie kompetencje, darzyt zaufaniem. A to znaczy bardzo dużo, gotowośc bowiem do czynu tlumiona, podcinana, zamykana grozi kwasem i fermentem.

Sp. ksiądz biskup Antoni Laubitz przeszedl juz ostatni egzamin.

Wielkim byl - ale tylko czlowiekiem. Niewạtpliwie też wygląda subsydiow ofiary najsw. $i$ modlitwy. Wiecej mu one teraz znacza, aniżeli holdy $i$ wspomnienia. Nie poskąpiq mu chyba serca i blagalnej pamięci wszyscy, co chyla czolo przed jego pamięcią.

X. Jozef Prądzyniski. 